Nalar: Journal of Islamic Studies

Vol. 2, No. 1, Juli 2018

\title{
Kenabian Siddharta Gautama dalam Al-Qur'an Menurut Penafsiran Al-Qasimi
}

\author{
Iva Fauziah \\ Universitas Islam Negri Sunan Kalijaga Yogyakarta, Indonesia \\ Ivafanziab83@gmail.com
}

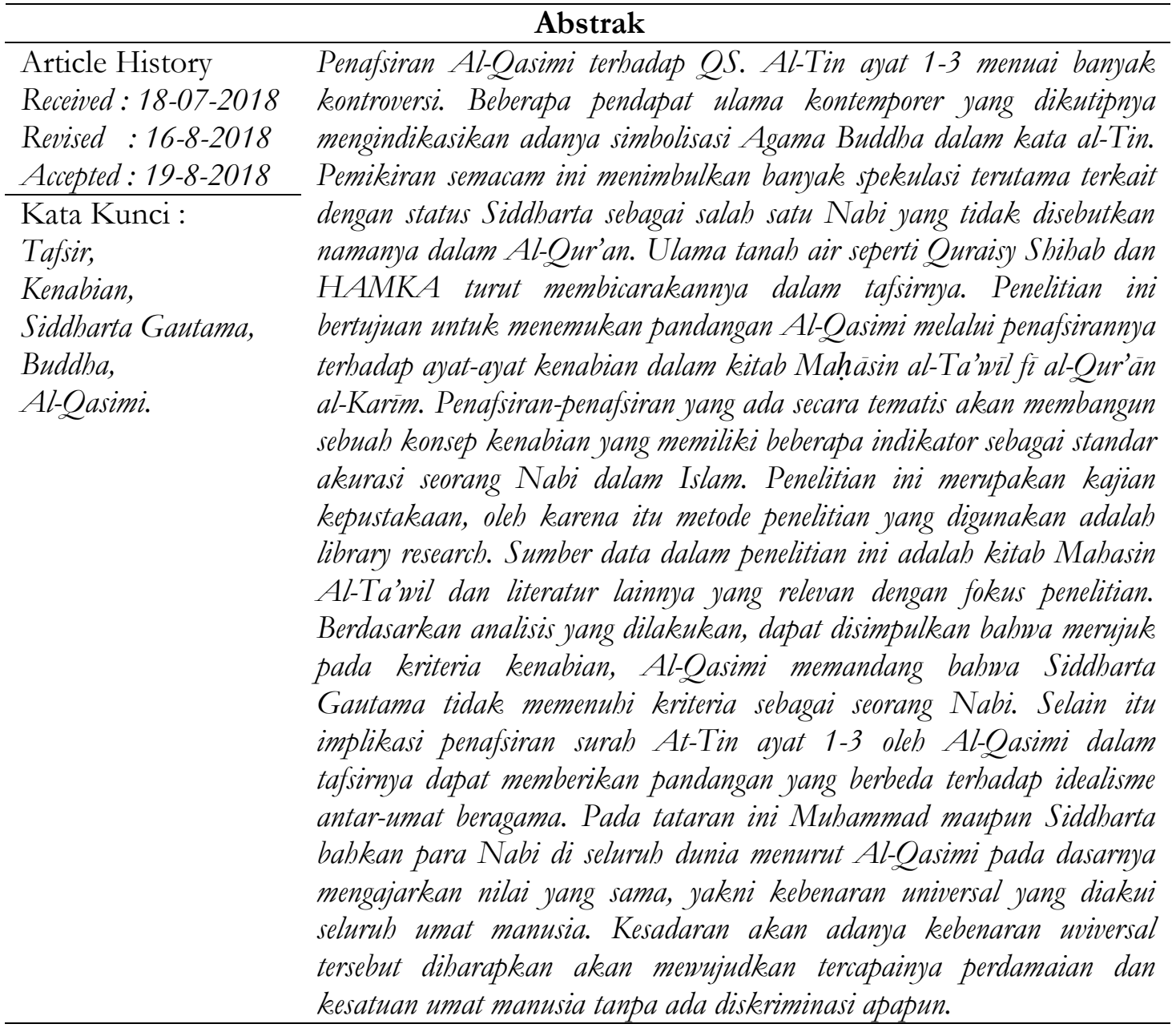

\section{Pendahuluan}

Nabi merupakan kedudukan yang paling agung setelah Tuhan dalam sebuah agama. Seorang nabi adalah seseorang yang sengaja diciptakan dengan kepribadian sempurna dengan misi memperbaiki kemanusiaan (Al-Qasimi M. J., 1978). Dalam kehidupan beragama, kenabian merupakan sesuatu yang mendesak dan sangat dibutuhkan oleh umat. Sebab, umat yang dalam keadaan sakit secara naluriah akan membutuhkan sesuatu sebagai obat baik secara lahir maupun batin. Karena para nabi adalah utusan yang menyampaikan panggilan langit pada penduduk bumi, maka mereka akan menenangkan akal dan ruh manusia dengan kebutuhan akan tuhan, serta mengatur lahiriah mereka dengan syari'at (Mughniyyah, 1993). 
Nalar: Journal of Islamic Studies

Vol. 2, No. 1, Juli 2018

Isu kenabian menjadi penuh kontroversi tatkala dibenturkan dengan ideologi berbagai macam agama di dunia. Agama seperti Yahudi, Kristen, dan Buddha, masingmasing memiliki tokoh yang dianggap berkedudukan suci sehingga patut menyandang status nabi, meskipun beberapa di antaranya ada yang menuhankannya. Terlebih setelah merebakya studi antar agama, wacana ini menjadi salah satu referensi bagi umat beragama sebagai wawasan baru untuk bersikap dan berperilaku di masyarakat. Dengan demikian, dapat dikatakan bahwa setiap penuturan para mufasir dan tokoh keagamaan terkait dengan isu-isu kenabian memiliki implikasinya tersendiri terhadap situasi yang sedang dihadapi.

Misalnya Ahmadiyah, yang menganggap bahwa Mirza Ghulam Ahmad sebagai nabi terakhir. Mereka mengagungkannya dalam al-Drikera sama seperti ketika mereka mengagungkan Muhammad dalam al-Qur'an. Dalam menanggapi prinsip semacam ini, umat memiliki kesimpulan yang berbeda-beda. Di kalangan umat Islam sendiri terdapat banyak pandangan, namun secara umum mereka menganggapnya sebagai pelecehan terhadap Muhammad saw, sehingga Ahmadiyah dihukumi murtad karena menyalahi keyakinan umat Islam bahwa Muhammad adalah khatamul anbiya'.

Problematika di atas merupakan contoh perbedaan prinsip tentang kenabian yang terjadi dalam tubuh umat Islam. Perbedaan dalam lingkup internal ini pun telah cukup menyita banyak perhatian publik, bahkan tak sedikit di antaranya yang mengambil sikap dan tindakan. Pada tataran ini sikap memaksakan kehendak dan keyakinan terhadap orang yang sudah memiliki ketetapan hati justru hanya akan semakin memperkeruh suasana. Akan tetapi, ketika dua keyakinan yang berbeda berhasil mendapati beberapa titik temu, paling tidak akan timbul rasa simpati, bahkan mampu mengurangi resistensi dan ketegangan yang terjadi di antara keduanya. Dengan demikian, implikasi dari adanya titik temu tersebut dapat ditujukan untuk mencapai perdamaian. Sebab, problematika di kalangan umat beragama masih terus berlanjut, terutama yang berkaitan dengan intoleransi. Dalam kondisi ini Muhammad Jamaluddin Al-Qasimi justru memunculkan sebuah wacana pemikiran yang sekilas menimbulkan kontroversi. Pemikiran tersebut adalah terkait penafsirannya terhadap surah At-Tin ayat 1-3 yang dihubungkannya dengan kenabian Siddharta Gautama.

Muhammad Jamaluddin Al-Qasimi memimpin gerakan modernisme pada awal abad ke-20 di Damaskus. Publikasinya cukup banyak mencakup beberapa disiplin ilmu keagamaan, seperti Hukum Islam, teologi, maupun tafsir, adat istiadat seorang muslim, juga Sejarah Arab. Aktivitasnya sebagai pendukung reformasi pemikiran keagamaan masih tertutup dari publik hingga iklim politik mereda setelah dibuatnya undang-undang kebebasan pers oleh Konstitusi Revolusioner Turki pada 1908. Pandangannya terkait dengan politik dan agama membuatnya mendapatkan tekanan dari Turki Usmani juga menimbulkan ketegangan dengan para sarjana konservatif. Bahkan dengan gagasan yang dibawanya, ia pernah dituduh memunculkan madzhab baru bernama Jamaliy, sehingga dalam beberapa waktu sempat mendekam di penjara pada tahun $1313 \mathrm{H}$ (Commins, 2002).

Latar belakangnya yang demikian membuat Al-Qasimi tidak segan untuk mengungkapkan semua pemikirannya. Hal paling menonjol dalam tulisan-tulisannya adalah perihal kembali pada al-Qur'an dan sunnah dengan tidak menjadikan keragaman sekte dan aliran sebagai biang perpecahan. Oleh karena itu, tak heran bila dalam banyak karyanya, AL-Qasimi banyak menyinggung isu-isu persatuan tanpa mempermasalahkan perbedaan, juga fanatisme terhadap suatu golongan yang tak jarang mengundang sinisme dan penolakan dari banyak pihak.

Kitab Mahāasin al-Ta'wĭl fì al-Qur'ān al-Karim merupakan salah satu karya besarnya yang ditulis pada masa terjadinya benturan di antara dua peradaban yang berbeda. Benturan yang terus-menerus antara Islam dengan gerakan internasional orientalisme dan 
Nalar: Journal of Islamic Studies

Vol. 2, No. 1, Juli 2018

misionarisme pada pertengahan kedua abad ke-19 dan awal abad ke-20, dimana serangan kolonialis terhadap dunia Islam mencapai puncaknya (Al-Muhtasib, 1997). Oleh karena itu, penulisan tafsir ini ditujukan untuk menunjukkan dan membela kebenaran agama, dimana pembenarannya bisa didapat dari dua arah (apabila menyangkut dua keyakinan berbeda). Semua yang dikemukakannya adalah demi persatuan umat, bukan ashabiyah maupun provokasi semata.

Terkait dengan konsep kenabian, Al-Qasimi memiliki gagasan yang unik dalam tafsirnya, yakni Siddharta Gautama atau Sakyamuni. Tokoh yang diangggap suci oleh umat Buddha tersebut disinyalir sebagai salah seorang Nabi di antara banyak Nabi yang tidak disebutkan namanya dalam al-Qur'an. Untuk memperluas wacana, Al-Qasimi turut mengutip beberapa penafsiran ulama yang relevan, seperti Ibnu Katsir, Ibnu Taimiyah, dan lainnya, baru kemudian memberi penjelasan tambahan dengan melihat realitas saat ini (AlQasimi M. J., 1978).

Penafsiran Al-Qasimi yang demikian, mendapat tanggapan yang serius dari mufasir tanah air, seperti Hamka dan Quraish Shihab. Hamka dalam tafsir Al-Azhar bahkan menyebutkan bahwa orang yang menafsirkan bahwa buah Tin dalam Al-Qur'an adalah pohon Bodhi tempat Budha bersemedi adalah orang yang belum mendalami secara menyeluruh filsafat Agama Budha (HAMKA, 1985). Berbeda dengan Hamka, Quraish Shihab menyebutkan secara eksplisit dalam tafsirnya bahwa menurut Al-Qasimi, Buddha adalah seorang Nabi meskipun tidak termasuk dalam kelompok dua puluh lima nabi yang nama-namanya secara jelas dan pasti disebutkan dalam al-Qur'an, sehingga menjadi kewajiban bagi setiap muslim untuk mengakui kenabian mereka, sambil meyakini bahwa masih banyak lagi nabi-nabi yang tidak disebut dalam al-Qur'an (Shihab, 2002).

Bila asumsi ini benar, maka setidaknya Al-Qasimi menyinggung beberapa penjelasan mengenai Dzulkifli a.s. dalam tafsirnya. Namun faktanya keterangan mengenai Dzulkifli dalam kitab tafsirnya sama sekali tidak menyinggung tentang Budha sedikitpun bahkan mengarah pada subjek lain. Sebagaimana keterangan dalam QS. Al-Anbiya' ayat 85, Al-Qasimi tidak memberikan pendapatnya terkait dengan hal ini. Sedangkan dalam QS. Shad ayat 48, Al-Qasimi hanya memberikan keterangan bahwa Dzulkifli adalah orang-orang pilihan yang diberi kenabian dan risalah sebagai hidayah dan petunjuk bagi manusia (AlQasimi M. J., 1978). Keterangan ini sangat umum mengingat jumlah nabi yang begitu banyak.

Kajian ini akan mengarah pada studi tentang penafsiran Al-Qasimi terhadap ayatayat yang berkaitan secara langsung maupun tak langsung mengenai kenabian secara spesifik. sebuah gambaran ide dari Al-Qasimi mengenai kenabian dalam tafsirnya. Parameter inilah yang akan mengukur sejauh mana konsep kenabian itu mengarah pada Siddharta, serta mengetahui implikasinya di masa sekarang ini. Untuk menganalisis pemikiran Al-Qasimi tersebut, kajian ini menggunakan metode library research (penelitian kepustakaan). Sumber data yang digunakan dalam kajian ini adalah kitab Mahäsin al-Ta'wil fì al-Qur'ān al-Karim dan literatur lainnya yang relevan dengan fokus kajian.

\section{Jamaluddin Al-Qasimi dan Kitab Mahāsin al-Ta'wīl}

Nama lengkapnya adalah Jamaluddin bin asy-Syaikh Muhammad Sa’id ad-Dimasyqi bin asy-Syaikh Muhammad Qasim al-Hallaq asy-Syafi'i al-Asy'ari (al-Kattani, 1982). AlQasimi lahir pada Hari Senin Bulan Jumadil 'Ula tahun 1283 H/1866 M, dan wafat pada hari Sabtu Bulan Jumadil 'Ula tahun 1332 H/1914 M. Al-Qasimi dilahirkan dan wafat di Damaskus (Al-Qasimi m. J., 2004). 
Nalar: Journal of Islamic Studies

Vol. 2, No. 1, Juli 2018

Salah satunya guru Al-Qasimi yang paling berpengaruh adalah Muhammad Abduh. Sejak perkenalannya dengan Abduh pada tahun 1904, Al-Qasimi mengganti gaya bahasa sajak yang selama ini digelutinya dengan gaya bahasa prosa dalam banyak karya tulisnya. Selain Muhammad Abduh, Al-Qasimi juga banyak dipengaruhi oleh pemikiran Ibnu Taimiyah dan Ibnu Katsir. Di samping itu, ada pula Syaikh al-Bakri al-Aththar dan Syaikh Abdu al-Raziq al-Bithar, dua ulama yang terkenal di jamannya (al-Muhtasib, 1997).

Al-Qasimi memegang madzhab Salaf dalam masalah agama dan membelanya dalam studi-studi maupun karya-karyanya. Madzhab salaf merupakan bentuk pelaksanaan AlQur'an dan as-Sunnah tanpa menambah dan mengurangi sedikitpun. Dalam menghadapi ikhtilaf, Al-Qasimi memilih sikap adil, moderat, dan mengikuti pandangan yang dibangun berdasarkan dalil, tanpa mencaci perbedaan atau membela secara membabi buta. Syaikh Rasyid Ridha juga mengatakan bahwa Al-Qasimi adalah pembaharu yang menjembatani antara petunjuk salaf dan perkembangan yang dibutuhkan oleh zaman. Di samping itu, AlQasimi juga menolak adanya taklid dan menyerukan dibukanya pintu ijtihad (Al-Qasimi m. J., 2004).

Kitab Mahāsin al-Ta'wül merupakan salah satu karya terpopuler dari Jamaluddin alQasimi. Tafsir ini mulai ditulis pada tanggal 10 Syawal $1317 \mathrm{H}$. Tafsir ini berjumlah 17 juz yang tercetak dalam 10 jilid terbitan Dar al-Ihya' al-Kutub al-'Arabiyah, Kairo. Karena kepopulerannya, kitab ini pernah diteliti oleh Muhammad Bahjat al-Baithar, salah seorang anggota Majma' al-'Ilmi al-'Arabi (al-Muhtasib, 1997). Kitab tafsir Mậàsin al-Ta'wñl muncul di tengah zaman, di mana terjadi benturan di antara dua peradaban yang berbeda. Benturan yang terus-menerus antara Islam dengan gerakan internasional orientalisme dan misionarisme. Benturan tersebut terjadi pada pertengahan kedua abad ke-19 dan awal abad ke-20, di mana serangan kolonialis kafir terhadap dunia Islam mencapai puncaknya. Benturan antara dua peradaban ini diiringi muatan kepentingan, yang bukan saja berkaitan dengan aspek teologis, juga berkaitan dengan aspek ekonomi dan aspek kekuasaan. Benturan dan perang wacana ini pun terjadi di tempat tinggal Al-Qasimi, yaitu Negeri Syam. Tak pelak lagi, Syam menjadi tempat persemaian yang subur bagi gerakan kaum misionaris dan para pengikutnya. Di tengah-tengah suasana inilah Al-Qasimi menulis karya tafsirnya.

Tafsir Al-Qasimi sarat dengan ayat dan hadis serta keterangan dari sahabat maupun tabi'in, di samping memperhatikan isu-isu aktual. Al-Qasimi juga terkadang mengutip beberapa keterangan dari Taurat dan Injil. Dalam keterangan tafsirnya, dia menyebutkan kebathilan-kebathilan yang diyakini oleh orang-orang Yahudi, serta orang-orang Nasrani, bahkan Al-Qasimi mampu menyusun bukti yang logis untuk membantah anggapananggapan yang memusuhi Islam. Bantahan tersebut juga diperkaya dengan pendapat para ulama, semisal Burhan al-Biqa'i dalam tafsirnya Al-Munāsabät, Khaeruddin al-Alusi dalam Jawāb al-Faṣihh, serta Ibnu Hazm dalam kitabnya Al-Faṣl (Al-Qasimi M. J., 1978).

Abd al-Majid Abd as-Salam al-Muhtasib memasukkan tafsir karya Al-Qasimi ini ke dalam kategori tafsir klasik, bersama al-Tafsìr al-Hädïs karya Muhammad Izzat Darwazat dan al-Tafsìr Al-Qur'än li AlQur'ān karya Abd al-Karim al Khatib. Alasan yang diberikan adalah karena tafsir ini selalu merujuk pada sumber-sumber klasik sebagai sumber penafsiran, baik berupa hadis-hadis Nabi maupun pendapatpendapat para saläf al-sälih. Walaupun demikian, Al-Qasimi tidak pernah mengabaikan aspek personality dan pendirian-pendiriannya. AlQasimi juga mengingat kondisi masyarakat pada zamannya. Untuk itu, ia selalu menyerang orang-orang yang melakukan bid'ah dan berbuat taklid, seraya memproklamirkan dibukanya 
Nalar: Journal of Islamic Studies

Vol. 2, No. 1, Juli 2018

pintu ijtihad. Upaya kerasnya dalam menentang bid'ah ini dipengaruhi oleh sikap Ibnu Taimiyah (al-Muhtasib, 1997).

\section{Nabi dan Kenabian dalam Islam}

Secara etimologis, kata nabi berasal dari Bahasa Arab, naba', yang berarti warta (alkhabar), berita, informasi, dan laporan. Bentuk jamaknya adalah nabiyyün dan anbiyä. Sedangkan nubuwwah adalah bentuk masdar (kata benda) dari naba'a yang berarti kenabian (prophecy, ramalan, atau propethood, kenabian), sifat nabi; yang berkenaan dengan nabi (Tim Penyusun Kamus Pusat Pembinaan dan Pengembangan, 1994). Kata ini disebutkan sebanyak 5 kali dalam al-Qur'an. Dalam Bahasa Inggris, nabi disebut dengan prophet yang berarti seseorang yang mengajarkan agama dan mengklaim mendapat inpirasi dari Tuhan (Baqi, 2001).

Secara istilah, kata nabi memiliki banyak definisi. Nabi adalah seseorang yang menerima wahyu dari Allah swt melalui perantara malaikat atau ilham maupun mimpi yang benar. Mereka disebut juga sebagai mubasysyir (pembawa berita baik, yaitu tentang ridha Allah dan kebahagiaan hidup di dunia dan akhirat bagi orang-orang yang mengikutinya) dan munzir (pemberi peringatan, balasan terhadap mereka yang ingkar). Keterangan lain menyatakan bahwa karunia kenabian ditetapkan secara tegas hanya untuk manusia yang berjenis kelamin laki-laki sebagaimana yang disebtkan dalam QS. An-Nahl ayat 43 dan QS. Al-Anbiya ayar 7 (Zainuddin, 1992).

Pembicaraan tentang nabi dan kenabian tidak terlepas dari term rasul (al-Rasūl) dan kerasulan (al-risälah). Secara tradisional, penulis-penulis muslim membuat perbedaan antara nabi dan rasul. Nabi adalah utusan Allah yang tidak membawa hukum (syari'at) dan mungkin pula kitab Allah kepada manusia. Sedangkan rasul yang bentuk jamaknya rusul yang berarti utusan, dan menurut istilah adalah utusan Allah yang membawakan hukum dan kitab Allah. Menurut pendapat yang masyhur, nabi adalah seorang yang menerima wahyu dari Allah swt tanpa ada kewajiban untuk menyampaikannya kepada orang lain, sedangkan rasul adalah orang yang menerima wahyu dari Allah dengan kewajiban menyampaikannya kepada manusia.

Terkait dengan sumber kenabian, Ibnu Arabi berpendapat bahwa kenabian para nabi merupakan perkara pemberian (maububi). Hal ini karena Ibnu Arabi kenabian bukanlah perkara usaha manusia (kasbi). Jadi seluruh syari'at dari sudut pandang kaum muslimin, merupakan perkara maububi. Sehingga kenabian merupakan suatu keistimewaan yang tak bisa diajarkan maupun dipelajari, karena ia murni berasal dari Tuhan. Definisi ini sejalan dengan pandangan Ahlussunah, yakni kenabian adalah pangkat yang diberikan oleh Allah kepada hamba-hamba yang dikehendaki-Nya tanpa diusahakan dan dengan jalan memberikan wahyu kepadanya. Dengan demikian, kemampuan seorang Nabi berhubungan dengan Malaikat Jibril tanpa diawali latihan, karena Allah telah menganugerahinya dengan kekuatan suci (Qudsiyah) (Arabi, t.t.t.).

Berdasarkan keberlangsungannya pada suatu masa, Abid Al-Jabiri membagi kenabian menjadi dua kategori kenabian. Pertama, kenabian yang terputus, yaitu kenabian yang telah disyari'atkan oleh Allah swt yang memuat tentang budud dan abkam, yang terjadi pada para nabi dan rasul dalam sejarah. Kedua, kenabian yang terus berlangsung, yaitu kenabian ma'rifat, meliputi kenabian 'irfan dan ilham. Kenabian yang terus berlangsung dapat diproses sebagaimana walayah, karena pada awalnya keduanya bisa diusahakan. Wali tidak hanya berdasar pada kenabian, melainkan juga berdasar pada kerasulan, sehingga seorang waliyullah akan mewarisi aspek kenabian dan kerisalahan sekaligus. Mereka yang 
Nalar: Journal of Islamic Studies

Vol. 2, No. 1, Juli 2018

mencapai fase ini selain para wali adalah muqarrabün, yakni mereka yang mengabdikan seluruh hidupnya kepada Allah swt (al-Jabiri, 1990).

Dilihat dari sisi dakwah, seorang nabi memiliki tiga hal dalam diri dan ajarannya; Pertama, Nabi tidak melakukan apapun yang bertentangan dengan tindakan rasional akal. Misalnya seperti menyatakan bahwa Sang Pencipta lebih dari satu jumlahnya. Sifat terjaganya dari kekeliruan ini dinamakan ismah. Kedua, Nabi menyeru makhluk agar patuh kepada Allah dan agar menghindarkan diri dari tindakan-tindakan mungkar. Ketiga, sebagai konsekuensi seruan para nabi, terdapat mukjizat dan tantangan-tantangan dalam menjalankan tugasnya (Muthahhari, 1991).

Keberadaan para Nabi merupakan peristiwa kesejarahan, yakni informasi mengenai adanya nabi telah ada sejak dulu secara mutawattir. Seorang nabi adalah manusia yang mendapatkan wahyu yang tidak mungkin setiap orang membawakannya. Dengan demikian, setiap orang yang mengaku dirinya sebagai Nabi dan rasul Allah dengan membawa syari'at sebagaimana syari'at yang dibawa oleh para nabi, maka dia adalah seorang nabi.

\section{Persoalan Seputar Mukjizat dan Wahyu}

Ada berbagai persoalan yang dikemukakan al-Qur'an mengenai mukjizat. Pertama, adalah perlunya mukjizat sebagai bukti bagi setiap misi kenabian. Kedua, adalah sebagai bukti. Ketiga, adalah pengunjukannya sesuai dengan izin Tuhan. Keempat, adalah bahwa ia perlu sebagai bukti kebenaran klaim-klaim para nabi, tetapi para nabi itu tidaklah terikat untuk menuruti begitu saja tuntutan kaumnya untuk memperlihatkan mukjizat apapun yang mereka minta. Dengan kata lain, para nabi itu tidaklah membuka suatu "pameran mukjizat" dan tidak mendirikan pabrik mukjizat (Muthahhari, 1991).

Ibnu Rusyd memandang bahwa mukjizat dapat dipahami bukan hanya berdasarkan ketetapan wahyu, melainkan juga melalui logika. Pemikiran manusia belum tentu membenarkan sesuatu kecuali setelah diketahui peristiwa itu terjadi pada diri seseorang beberapa kali. Bila akal belum mengetahui maksud sesuatu, akal berhenti dulu sampai ia mengetahui maksud sebenarnya. Mukjizat itu adakalanya pada diri risalah itu sendiri, dan adakalanya pula berada di luar isi dari intisarinya. Perbedaan di antara keduanya amat luas sekali ruang lingkupnya disebabkan perbedaan lingkungan dari mukjizat itu begitupun risalat yang menyertainya. Pada masa-masa pertama yang diutamakan adalah hal-hal luar biasa dalam bentuk materi semata. Mengenai hakikat-hakikat yang terkandung dalam agama itu sendiri, maka kedudukannya ialah sebagai nomor dua. Hingga akhirnya datanglah Islam, maka dihentikannya mukjizat-mukjizat yang bersifat materiil dan ditonjolkanlah mukjizat rasional, nilai-nilai kerohanian dari risalah. Selain itu ditetapkan pula bahwa hal-hal luar biasa yang mengukuhkan agama-agama di masa silam. Pertama, tidak terlarang mendustakannya. Kedua, tidak ada artinya menuntut orang lain untuk mempercayainya (AlGhazali, 1986).

Wahyu juga merupakan sesuatu yang urgen dalam isu kenabian. Secara etimologis, kata wahyu berasal dari kata "wahy" yang memiliki beberapa arti, di antaranya adalah suara, tulisan, isyarat, bisikan, dan paham. Sedangkan secara terminologis, menurut Muhammad Abduh, wahyu merupakan informasi dari Allah kepada Nabi-nabinya mengenai sebuah ajaran hukum atau ajaran lainnya. Kata wahyu digunakan beberapa kali dalam al-Qur'an. Berbagai penggunaannya menunjukkan bahwa wahyu tidak saja berkaitan dengan manusia, melainkan juga mengalir pada tiap-tiap sesuatu, atau pada diri setiap makhluk hidup. Perbedaannya hanyalah dalam derajat wahyu dan bimbingan yang sesuai dengan perkembangan makhluk yang bersangkutan. Derajat tertinggi wahyu adalah yang diterima oleh para nabi (Muthahhari, 1991). 
Nalar: Journal of Islamic Studies

Vol. 2, No. 1, Juli 2018

Wahyu adalah bimbingan yang berada di atas derajat indera dan akal, dan merupakan kualitas yang diperoleh secara sadar. Sehingga wahyu bukanlah semacam insting yang merupakan kualitas alamiah (bawaan) yang bersifat tidak sadar. Selain itu, wahyu juga berada di bawah derajat indera dan akal. Menurut hukum penciptaan, insting diberikan pada binatang yang berada di level lebih rendah. Seiring tumbuhnya panca indera dan akal, insting akan menjadi lemah dan berkurang, hingga manusia yang memiliki sistem pemikiran yang paling berkembang memiliki instink yang paling lemah. Dengan demikian, wahyu amat jauh berbeda dengan insting (Iqbal, 2002).

\section{Seputar Kenabian dalam Agama Buddha}

Dalam ajaran agama yang muncul pada abad-4 SM ini, tidak ada yang pantas disebut dengan "Tuhan", atau sebagai "Yang Maha". Hal ini karena tidak ditemukan ajaran tentang Tuhan atau tokoh yang dipertuhankan bahkan dalam kitab-kitabnya (Pitaka). Tujuan hidup bukanlah untuk kembali kepada asalnya, yaitu Tuhan, melainkan untuk masuk ke dalam nirwana, pemadaman, suatu suasana yang tanpa kemauan, tanpa perasaan, tanpa keinginan dan kesadaran, sehingga seseorang tidak lagi terbakar oleh nafsunya.

Secara teori, Buddha Gautama tidak mengakui adanya tokoh yang dipertuhan, namun secara praktis dapat dirumuskan meskipun masih samar dan kabur. Memang tidak ada sebutan Tuhan maupun tokoh yang dipertuhan, akan tetapi berdasarkan fakta, di dalam ajaran Buddha manusia rindu akan kelepasannya (kebebasan) dan mencari-cari akan "Apa yang tak dilihatnya". Dengan demikian, dapat dikatakan bahwa Buddhisme adalah suatu agama, yang dengannya manusia berusaha mencari Tuhannya. Tuhan sukar ditemukan, dan tokoh yang dikaburkan menjadi sesuatu yang tak berpribadi, sehingga dalam konteks ini tidak ada hubungan "aku-engkau" antara manusia dengan yang dipertuhan (Hadiwijono, 1989).

Inti dari ajaran Buddha adalah pencerahan menuju nirwana. Memang tokoh urgen dalam sebuah agama tidak dianggap penting, namun jalan falsafah itulah yang penting. Dalam inti ajaran, yang ada adalah nirwana, pemadaman (hawa nafsu), situasi padam, bukan tokoh yang memadamkan. Tidak ada gagasan tentang suatu pribadi yang ada di balik suasana damai seperti itu. Tidak ada gagasan tentang pemberi hukum, yang ada adalah hukum, tata tertib (karma) baik yang alamiah maupun yang moril. Meskipun ketidakadaan tokoh ini dianggap sebagai pemikiran yang negatif, namun bagi pemeluk agama ini, seruan kepada Buddha sudah lebih dari cukup untuk menutupi kebutuhan ini, meskipun status tidak dianggap penting.

Buddha Gautama meninggalkan istana saat usianya 29 tahun untuk mencari seseorang yang dapat membimbingnya. Namun setelah berkelana tanpa jawaban yang pasti, Siddharta memutuskan berhenti mencari guru dan mendaulatkan hati dan pikirannya sendiri sebagai guru satu-satunya. Siddharta kemudian mulai mencari cara sendiri untuk menemukan Buddha dalam dirinya. Dengan cara ini pula ia menemukan hukum-hukum kebenaran yang menjadi tujuan disiplin diri yang ia jalani (Okawa, 2004). Kisah pencarian ini memperlihatkan bahwa tokoh Siddharta tidak menemukan sesuatu yang dicari melalui banyak guru yang dia temui, melainkan dia mendaulatkan diri sendiri sebagai sumber pengajaran. Hal itu tidak menjadi persoalan karena yang ingin disampaikan bukanlah keselamatan dalam arti agama wahyu, melainkan suatu kebenaran universal yang dapat dicapai oleh manusia sendiri. Tanggapan terhadap manusia menjadi isi pokok yang disebut sebagai situasi penderitaan (Saragi, 2000).

Dalam agama Buddha dikemukakan bahwa kehidupan Siddharta sebagai pribadi tidaklah penting. Meski demikian, Buddha diakui sebagai sebuah gelar, suatu jabatan atau 
Nalar: Journal of Islamic Studies

Vol. 2, No. 1, Juli 2018

seorang tokoh yang pernah menjelma pada seseorang. Menurut kepercayaan Buddhis sebelum tahap zaman sekarang ini, sudah ada tahap zaman-zaman yang tak terbilang banyaknya, dimana setiap zaman memiliki Buddhanya sendiri-sendiri. Dengan demikian diyakini ada banyak Buddha, yakni orang yang mendapatkan pencerahan Buddhi.

\section{Tafsir QS Al-Tīn ayat 1-3 dalam Kitab Mahasin al-Ta'wīl}

Terdapat beberapa penafsiran selain Al-Qasimi yang juga menafsirkan surah At-Tin ayat 1-3. Mujahid dan Hasan mengatakan bahwa al-tin diartikan sebagai sesuatu yang dimakan, dan zaitun adalah sesuatu yang diperas. Kedua buah tersebut banyak faedahnya dan besar manfaatnya. Qatadah, al-tin diartikan sebagai gunung yang di atasnya terdapat Kota Damaskus, sedangkan al-zaitun di atasnya ada Baitul Maqdis. Ibnu Abbas menafsirkan at-tin adalah Masjid Nuh yang dibangun di atas Judiy (bukit), dan al-zaitun adalah Bait alMaqdis (Al-Qasimi M. J., 1978). Sebagian ulama kontemporer menjelaskan bahwa al-tin yang dimaksud adalah sebuah pohon, yakni Pohon Bodhi tempat bersemedinya pendiri Agama Buddha ketika sedang mencari wahyu, yang ajarannya di kemudian hari telah berubah dari hakikat aslinya.

Menanggapi beberapa penafsiran di atas, Al-Qasimi berpandangan bahwa pendapat yang paling rajib (kuat) menurutnya, apabila benar pendapat mengenai ayat ini, bahwa dia (Buddha) benar-benar seorang nabi, yang disebut dengan Sakyamuni atau Gautama. Oleh karena itu, awal kebangkitannya adalah saat ia berteduh di bawah Pohon Tin yang besar dan pada saat itulah turun wahyu kepadanya, lalu ia diutus menjadi seorang rasul Allah. Setan berkali-kali mencoba memperdayakannya, namun tidak berhasil. Pohon besar itu menjadi pohon yang suci menurut kepercayaan penganut Agama Buddha, yang mereka namai pula dengan sebutan Accapala."

Al-Qasimi juga mengatakan bahwa dalam ayat-ayat ini Allah menyebutkan empat agama besar yang dianut manusia yang ditetapkan Allah sebagai pembimbing dan memberi manfat kepada mereka di dunia dan akhirat. Allah menyebutkan Buddha dan Nasrani lebih awal untuk mengenalkan manusia kepada keutamaan dan kasih sayang, sedangkan menyebutkan Yahudi dan Islam kemudian untuk menyatakan pendidikan secara tegas, serta keadilan. Begitulah Islam dimulai dengan kelemahlembutan dan toleransi, baru kemudian dengan syari'at yang keras dan hukuman-hukuman. Allah menggambarkan kedua agama kasih dengan buah-buahan, sedangkan menggambarkan agama keadilan dengan gunung dan kota yang memiliki banyak gunung, yakni Mekah.

Penganut keempat agama tersebut merupakan yang terbesar jumlahnya di dunia. Secara urut disebutkan dalam ayat ini berdasarkan derajat keshahihannya sehubungan dengan adanya pokok-pokok yang utama. Maka Allah memulai sumpah dengan Buddha, karena keshahihannya paling sedikit dan telah jauh menyimpang dari asalnya. Hal ini sebagaimana manusia mengawali sumpahnya dengan sesuatu yang kecil menuju ke tingkat selanjutnya yang lebih besar. Setelah itu disebut Nasrani, lalu Yahudi karena lebih shahih. Terakhir adalah Islam yang paling shahih di antara semuanya (Al-Qasimi M. J., 1978).

Melihat uraian di atas ada dua hal yang perlu digarisbawahi, yakni bahwa penafsiran Al-Qasimi tentang Buddha bersumber pada ulama kontemporer yang ada pada saat itu. Meski demikian, kata wa al-räjibu indanā seolah-olah menyimpulkan bahwa pernyataan sebelumnya (Gautama adalah nabi) adalah benar adanya. Dalam beberapa penafsirannya, Al-Qasimi menggunakan kata wa al-räjïhu indanā sebagai pernyataan sikapnya terhadap suatu penafsiran. Hal ini pula lah yang menjadi pertimbangan Quraish Shihab dalam mengutip pendapat Al-Qasimi dalam tafsirnya Al-Misbāḥ dengan terang-terangan. Quraish Shihab dalam tafsir Al-Misbah menyatakan bahwa dalam tafsirnya Mabasin Al-Ta'wil Al- 
Nalar: Journal of Islamic Studies

Vol. 2, No. 1, Juli 2018

Qasimi menyatakan bahwa al-tin adalah nama pohon tempat pendiri Agama Buddha. Pohon ini dinamai Bodhi (ficus religiosa) atau Pohon Ara suci, yang terdapat di kota kecil Gaya, di daerah Bihar. Buddha, menurut Al-Qasimi adalah seorang nabi walaupun beliau tidak termasuk dalam kelompok dua puluh lima nabi yang nama-namanya secara jelas dan pasti disebutkan dalam al-Qur'an. Oleh karena itu menjadi kewajiban bagi setiap muslim untuk mengakui kenabian mereka sambil meyakini bahwa masih banyak lagi nabi-nabi yang tidak disebut dalam al-Qur'an (Shihab, 2002).

Pendapat Quraish Shihab tersebut senada dengan pendapat Hamka dalam tafsir AlAzhar. Dalam tafsirnya tersebut Hamka mengatakan bahwa mufassir yang menafsirkan pohon Tin dalam Al-Qur'an adalah pohon Bodhi tempat Buddha bersemedi besar kemungkinan belum mendalami benar-benar filsafat agama Buddha. Hal ini karena pada dasarnya berdasarkan penelitian ahli, Buddha justru lebih banyak mengajarkan filsafat menghadapi hidup ini dan tidak membicarakan tentang ketuhanan. Lalu pengikut Buddha yang datang belakangan memuaskan hati mereka dengan menuhankan Buddha itu sendiri. Hamka menambahkan bahwa namun ada orang ulama besar dari Arabia dan Sudan, Syaikh Ahmad Soorkati pernah pula menyatakan pemikiran beliau, kemungkinan besar sekali bahwa yang dimaksud dengan seorang rasul Allah yang tersebut namanya dalam al-Qur'an Drulkifli, itulah Buddha (HAMKA, 1985).

Merujuk pada pendapat Hamka tersebut, besar kemungkinan mufassir dimaksud tersebut adalah Al-Qasimi. Keterangan tentang penafsiran Syaikh Ahmad Soorkati pada dasarnya ingin menunjukkan bahwa ada orang lain yang memiriki pendapat yang mirip dengan Al-Qasimi bahwa Gautama adalah seorang Nabi. Meskipun dalam konteks ini penafsiran tentang Nabi Dzulkifli menurut Hamka adalah pendapat pribadi Syaikh Ahmad Soorkati.

Al-Qasimi dalam tafsirnya memberikan keterangan bahwa Dzulkifli a.s. adalah Hiezkiel. Keterangan ini menunjukkan bahwa penuturan Syaikh Ahmad Soorkati tidak sepenuhnya sesuai dengan gagasan Al-Qasimi. Jika tidak, maka Buddha Gautama adalah Dzulkifli sekaligus Hiezkiel sehingga pandangan ini menyalahi fakta sejarah. Ibnu Katsir membantah pandangan tersebut dalam kitab Qissatu Al-Anbiya (Kisah Para Nabi). Menurut Ibnu Katsir Dzulkifli maupun Hiezkiel memiliki riwayat dan masa hidup yang berbeda (Katsir, 2008). Meski demikian, Al-Qasimi juga mengutip bahwa Ibnu Katsir hanya memberikan keterangan bahwa nama Dzulkifli tidak akan disandingkan dengan para nabi apabila dia bukan seorang nabi, tanpa menambahkan keterangan apapun (Al-Qasimi M. J., 1978).

Terlepas dari berbagai perdebatan di atas, dalam mengungkapkan gagasannya pun Al-Qasimi tidak memaparkan banyak alasan yang menyinggung kenabian, kecuali masalah wahyu. Sedangkan status wahyu ini pun masih dipertanyakan, apakah sama halnya dengan nabi-nabi Allah yang lain atau tidak. Oleh karena itu, untuk menekan spekulasi, perlu adanya bukti untuk melihat kesesuaian antara gagasan Al-Qasimi tersebut dengan konsep kenabian yang utuh dalam tafsirnya.

\section{Definisi Kenabian menurut Al-Qasimi}

Kenabian dalam pandangan Al-Qasimi merupakan suatu bentuk pengetahuan, kecerdasan, dan ilmu yang paling agung yang khusus diajarkan oleh Allah untuk para nabi. Sedangkan nabi adalah beberapa manusia yang dilebihkan atas sebagian makhluk-Nya, serta memberitakan kepada mereka perintah, kemudian mengutusnya kepada umat manusia. Allah juga menurunkan wahyu kepada mereka, kepada sebagian mereka diturunkan kitab 
Nalar: Journal of Islamic Studies

Vol. 2, No. 1, Juli 2018

yang sempurna. Sehingga, turunnya kitab dalam hal ini bukan merupakan satu syarat adanya kenabian.

Sebagaimana unsur keilahian yang dimiliki oleh Allah, nabi memiliki unsur kerisalahan. Risalah merupakan sesuatu yang diwahyukan, dalam jangka waktu yang panjang, dengan bentuk yang bermacam-macam. Dalam hal ini bisa dimaknai dengan perintah dan larangan, nasehat dan paksaan, berita gembira dan ancaman, dan lainnya. Perlu diketahui bahwa risalah para nabi hanya satu, yaitu tauhid. Untuk memperkuat argumentasinya tersebut Al-Qasimi mengutip Hadis yang diriwayatkan oleh Bukhari sebagai kerikut :

"Kita, sekalian para nabi, adalah cabang-cabang dari suatu pangkal, (yakni) agama kita adalah satu." (HR. Bukhari)

Sedangkan dalam riwayat Muslim, disebutkan:

Dari Abu Hurairah r.a Rasulullah saw bersabda, "Aku adalah paling utamanya manusia dalam pandangan Ibnu Maryam di dunia dan akbirat, dan para nabi itu bersaudara dalam satu pangkal, ibu-ibu mereka berbeda, namun agama mereka satu.” (Al-Qasimi M. J., 1978)

Pengertian risalah ini juga berdekatan dengan kalimatin sawa'. Dengan demikian kerisalahan dapat diartikan dengan suatu perkataan yang lurus yang tidak condong kepada atheisme maupun kemusyrikan, yang disepakati oleh semua rasul, serta termaktub dalam semua kitab yang diturunkan oleh Allah SWT. Allah menjadikan alur kenabian pada satu bayt (bangunan, keluarga, famili) dan tidak mengeluarkan kemuliaannya ke arah lain. karena Allah tidak akan mengutus seorang nabi dari nasab yang lemah, sebagaimana dalam Q.S. Ali Imran ayat 33. Adapun kalimat dzurriyyatan ba'dhuba min ba'dhin merupakan penegasan tetapnya jalur nasab yang akan memikul beban kenabian. (Al-Qasimi M. J., 1978)

Dalam karyanya Daläi al-Tawbid, Al-Qasimi menyebutkan beberapa tanda kenabian selanjutnya. Tanda-tanda tersebut diantaranya sesuatu yang bisa nampak secara kasat mata, yang diminta oleh seseorang, terkadang karena kurang dapat membedakan antara kalam ilahi dengan kalam manusia biasa, atau terkadang kurang percaya atau menentang, sebagaimana mukjizat yang dipinta oleh orang-orang kafir supaya nabi menunjukkan di depan mata mereka. Tanda-tanda tersebut menurut Al-Qasimi disebutkan al-Qur'an dalam surah Al-Isra' ayat 90 dan 93 (Al-Qasimi M. J., t.t.t).

\section{Siddharta: Nabi atau Bukan?}

Pada pembahasan sebelumnya telah diketahui beberapa tanda kenabian dalam pandangan Al-Qasimi. Tanda-tanda tersebut sebagai penentu sejauh mana kesesuaian tanda-tanda tersebut dengan pribadi Siddharta. Secara spesifik tanda-tanda tersebut sebagai berikut. Pertama, memiliki wujud fisik dan akhlak yang sempurna. Wujud fisik seorang Buddha, dapat dilihat melalui 32 ciri yang tertera dalam Mahapadana Sutta, dan juga dalam Lakkhana Sutta, Sutta Pitaka, Digha Nikaya, Sutta XXX, disebutkan 32 Tanda Istimewa Manusia Agung (Maha Purisa Lakkhana) yang dimiliki setiap Sammasambuddha (Hansen, 2008). Kedua, termasuk dalam garis keturunan para nabi (żurriyyah). Siddharta adalah putra dari Raja Sudhoddana dan Ratu Maha Maya Dewi. Ia adalah penerus Kerajaan Kapilawastu dari Suku Sakya (Hansen, 2008). Oleh karena itu, dapat dipastikan bahwa Siddharta tidak termasuk dalam alur kenabian yang telah digariskan Allah kepada keturunan Adam a.s, Nuh a.s, Ibrahim a.s, dan Ali Imran yang berasal dari semenanjung Arab. Apabila dikatakan bahwa Buddha merupakan salah satu nabi yang tidak disebut namanya dalam al-Qur'an, bukan berarti nabi berasal dari seluruh pelosok dunia, melainkan Allah telah memilih Suku Arab sebagai tempat berlangsungnya alur kenabian. 
Nalar: Journal of Islamic Studies

Vol. 2, No. 1, Juli 2018

Ketiga, dapat mengungkap hal-hal ghaib. Ketika Siddharta Gautama mendaulatkan dirinya sebagai guru yang tiada bandingnya. Realitas ini secara tidak langsung menunjukkan bahwa tidak ada sesuatu pun yang dapat memberi pengetahuan apapun kepadanya, bahkan manusia maupun yang lainnya. Bagi Siddharta, tabir telah terbuka sehingga tidak ada yang tidak diketahuinya. Dalam hal ini dia menganggap dirinya sebagai yang tiada bandingnya meskipun tidak menuhankan dirinya sendiri. Terkait dengan ramalan, dalam Kitab Suci Tripitaka berbahasa Pali tepatnya pada Digha Nikaya Cakkavatti Sihanada Sutta syair nomor 25, memuat perkatan ramalan Buddha yang berbunyi :

"Para bhikkhu, pada masa kehidupan orang-orang ini, di dalam dunia akan muncul seorang Bhagava Arahat Sammasambuddha bernama Metteyya (Pali), yang sempurna dalam pengetahuan dan pelaksanaannya, sempurna menempuh jalan, pengenal segenap alam, pembimbing manusia yang tiada taranya, yang sadar serta yang patut dimuliakan, yang sama seperti saya sekarang,...” (JR, 1997)

Ramalan tersebut di masa kini banyak dikaitkan dengan kedatangan Imam Mahdi bagi umat kristiani dan Muhammad bagi kaum umat muslim. Terlepas dari kontroversi tersebut, tidak ada sumber ilham lain bagi Buddha melainkan berasal dari dirinya sendiri.

Keempat, memiliki mukjizat. Keistimewaan yang dimiliki Siddharta adalah pencapaiannya terhadap dhamma, yakni terbebas dari segala samsara dan terbukanya semua tabir. Ketercapaian semacam ini, bukanlah suatu penguat karena dalam konsep Buddhisme, tidak ada yang dikuatkan maupun menguatkan, yang ada hanya menguatkan diri sendiri dengan disiplin yang tekun. Dengan demikian bila dilihat dari konsep kenabian Islam, keistimewaan tersebut bukanlah mukjizat karena tidak memenuhi unsur-unsur yang mengharuskannya ada, seperti penolakan yang kuat dari suatu kaum atau ancaman dari musuh (Utomo, 2017). Kelima, dapat menangkap pesan-pesan wahyu. Para nabi umat Islam selalu berbicara sesuai dengan wahyu yang diturunkan-Nya, begitupula dalam mengambil keputusan. Sebagaimana disebutkan Al-Qur'an surah Al-An'am ayat 50 yang menjelaskan bahwa ijtihad seorang nabi hanya akan terjadi setelah turun wahyu dari Allah swt. Lain halnya dengan Siddharta Gautama, ia mendaulatkan dirinya sendiri sebagai sumber pengajaran. Hal itu tidak menjadi persoalan karena yang ingin disampaikan bukanlah keselamatan dalam arti agama wahyu, melainkan suatu kebenaran universal yang dicapai oleh manusia sendiri. Tanggapan terhadap manusia menjadi isi pokok yang disebut sebagai situasi penderitaan (suffering). Tanggapan ini terealisasi dengan diterimanya beragam budaya dan tuntutan yang merupakan sifat utama Buddha. Dengan demikian, tidak ada unsur kebergantungan terhadap sesuatu atau menerima sesuatu dari yang lain selain dari dirinya sendiri (Saragi, 2000).

Keenam, menyeru kepada tauhid dan menegakkan syari'at. Syari'at para nabi adalah satu, yakni Tauhid. Tauhid inilah bersumber dari wahyu yang memiliki ide sentral sebagai konsepsi religius, yakni bahwa Allah adalah sumber segala kekuatan, pengetahuan, kebijaksanaan, kebaikan, keadilan, dan kasih sayang. Dalam Al-Qur'an surah Al-Anbiya ayat 25 dan surah An-Nahl ayat 36 disebutkan bahwa setiap orang yang diangkat menjadi rasul Allah, akan membawa ajaran tauhid dan mengajarkan untuk beribadah kepada Allah semata. Dengan demikian dalam pandangan Al-Qasimi, Buddha dari India, bahkan Zoroaster dari Persia, dan Konghucu dari Cina tidak dapat dimasukkan dalam golongan utusan Allah, karena tidak mengajarkan prinsip-prinsip dakwah yang dijunjung oleh setiap nabi, yakni ajaran tauhid (Al-Qasimi M. J., 1978).

Pembicaraan mengenai syariat pada umumnya berkaitan dengan agama-agama wahyu, sedangkan Buddha merupakan agama non wahyu yang hanya terkait dengan filsafat kehidupan manusia. Dalam hal ini, pembicaraan mengenai Tuhan menjadi tidak relevan 
Nalar: Journal of Islamic Studies

Vol. 2, No. 1, Juli 2018

disebabkan perbedaan konsep pangkalnya. Islam adalah agama monotheisme, sedangkan Buddha cenderung pada atheisme meskipun para pengikut pada generasi selanjutnya ada yang menuhankannya. Akan tetapi secara umum, anggapan ini masih ada yang menolak dari kalangan pemeluknya sendiri. Sebab Buddha Gautama tidak mengajarkan ketuhanan, dan tidak pula mengaku sebagai utusan. Pernyataan ini sejalan dengan penuturan Wahyu Utomo selaku Sekretaris Umum di Vihara Mendut. Bagi umat Buddha, Siddharta adalah sosok guru yang berhasil menemukan pencerahan. Apabila dibenturkan dengan prinsip teologi yang ada dalam Agama Buddha, permasalahan tentang tuhan menjadi sangat beragam sesuai dengan sekte yang dianut oleh masing-masing umat. Misalnya sekte Theravada, sekte ini menganggap Buddha Gautama sebagai guru, namun lebih dalam lagi tuhan dalam Buddhisme memang ada, namun bukan Gautama. Ia disebut sebagai Sang Hyang Addhi Buddha, sebagai Yang Mutlak, Yang Utama, Yang Tak Musnah dan Tak Dilahirkan. Dalam konteks ini prinsip tersebut merupakan bentuk penyesuaian dengan sila pertama Pancasila, yakni Ketuhanan Yang Maha Esa (Utomo, 2017).

Terkait dengan kenabian, poin-poin yang telah dijabarkan di atas menjadi tolok ukur sejauh mana Siddharta melangkah ke dalam konsep kenabian Al-Qasimi. Pada akhirnya, hanya ada satu poin yang sesuai dengan ciri-ciri kenabian yang dibangun dari tafsir Mậäsin al-Ta'wīl. Hal ini berarti menurut pandangan Al-Qasimi secara menyeluruh, Siddharta bukanlah seorang nabi. Menurut Utomo, hal ini sesuai dengan konsep agama Buddha yang tidak menganggap Buddha Gautama sebagai Nabi, sebab seorang Nabi harus memiliki tuhan, mukjizat, dan menerima wahyu. Namun lebih jauh, umat Buddha mentolerir predikat kenabian yang dilekatkan apabila hal itu mengandung manfaat. Sebab bagi umat Buddha yang terpenting adalah ajaran Buddha Gautama, bukan sosoknya sebagai sesuatu yang spesial.

\section{Implikasi Penuturan Al-Qasimi}

Hubungan antara Islam dan Buddha tidak sama sebagaimana hubungan Islam dengan Yahudi, Nasrani, maupun Zoroastrian. Perbedaan ini karena Buddha tidak termasuk dalam ablul kitab yang sedikit banyak disinggung dalam Al-Qur'an. Di samping itu, Al-Qur'an tidak memiliki perangkat lebih untuk membicarakan Buddhisme di luar tema-tema politheistik yang disamakan dengan berhala. Dengan demikian ketika membicarakan hubungan antara Islam dan Budhha, pola yang dibangun bisa seputar konfrontasi, penyesuaian (adjudgement), maupun mengarah pada tema-tema mistis (Scott, 1995).

Implikasi penuturan Al-Qasimi ini lebih mengarah pada pola kedua yakni penyesuaian, dimana dalam suatu ajaran itu ada kesamaan dengan ajaran lainnya. Dalam hal ini, Syahrastani juga mengungkap bahwa ajaran Buddha itu lebih dekat dengan ajaran para sufi. Di antaranya seperti konsep pencerahan dalam agama Buddha dengan konsep itlaq dalam sufisme, begitu pula dengan sunyata dan fana' (Scott, 1995). Persamaan-persamaan ini mengarah pada implikasi yang lebih luas dan modern. Untuk masa sekarang ini, dimana setiap manusia bebas memilih dan memeluk agamanya masing-masing tidak relevan lagi untuk mencari-cari perbedaan dan konfrontasi di bidang mu'ammalah keduniawian, terlebih dalam kehidupan antarumat beragama.

Tema besar yang coba diungkap oleh Al-Qasimi adalah adanya persamaan wahyu ilahi yang turun kepada keempat Nabi-Nya, yang mewakili setiap agama besar di dunia, yaitu Islam, Yahudi, Nasrani, dan Buddha. Dalam penafsiran ini, disebutkan pula bahwa meskipun pada agama-agama tersebut terdapat inhiraf, namun tetap dalam satu naungan 
Nalar: Journal of Islamic Studies

Vol. 2, No. 1, Juli 2018

suci wahyu ilahi. Gagasan Al-Qasimi ini identik dengan paham pluralisme yang menyamaratakan semua agama.

Terlepas dari kontroversi yang ada, tujuan besar Al-Qasimi tetap ditujukan pada tercapainya perdamaian dan kesatuan umat manusia tanpa ada diskriminasi apapun. Muhammad SAW dan Buddha Gautama sama-sama berstatus pemimpin agama yang mengedepankan kemanusiaan dan mengajarkan untuk memusnahkan segala macam ilusi yang menimbulkan perpecahan akibat ego manusia. Kedua tokoh ini sama-sama berusaha melawan kezaliman dan mengentaskan kesengsaraan umat demi membentuk kehidupan yang lebih baik.

\section{Kesimpulan}

Jamaluddin Al-Qasimi menyatakan bahwa kenabian merupakan suatu bentuk pengetahuan, kecerdasan, dan ilmu yang paling agung yang khusus diajarkan oleh Allah untuk para Nabi. Terdapat beberapa kriteria kenabian menurut Al-Qasimi. Pertama, memiliki wujud fisik dan akhlak yang sempurna. Kedua, memiliki kecerdasan yang luar biasa baik secara inteligensi, emosional, maupun spiritual yang bersih dari hawa nafsu. Ketiga, termasuk dalam garis keturunan para nabi (zurriyyah). Keempat, dapat mengungkap hal-hal ghaib. Kelima, mempunyai mukjizat. Keenam, dapat menangkap pesan-pesan wahyu. Ketujuh, menyeru kepada tauhid dan menyampaikan syari'at Allah. Merujuk pada kriteria tersebut, menurut Al-Qasimi Siddharta Gautama tidak memenuhi kriteria sebagai seorang Nabi.

Adapun implikasi penuturan Al-Qasimi tentang kenabian dalam konteks masa sekarang ini lebih tertuju pada pola interaksi yang paling sesuai dengan kehidupan antarumat beragama saat ini, yakni adjudgement (penyesuaian), dimana dalam suatu ajaran itu ada kesamaan dengan ajaran lainnya bukan konfrontasi. Meskipun dalam Agama Yahudi, Nasrani dan Buddha terdapat inbiraf, namun ketiga agama ini tetap dalam satu naungan suci wahyu ilahi dalam sudut pandang masing-masing. Pada tataran ini Al-Qasimi berharap dengan adanya penafsiran tentang konsep kenabian tersebut akan tercapainya perdamaian dan kesatuan umat manusia tanpa ada diskriminasi apapun. 


\section{Daftar Pustaka}

Al-Ghazali, M. 1986. Aqidah Islam. Jakarta: Pedoman Ilmu Jaya.

Al-Jabiri, M. A. 1990. Bunyah al-'Aql al-'Arabi, Diräsah Tablïliyah Naqdiyah li Nudūm alMa 'rifah fi al-ŚSaqüah al-'Arabiyah. Beirut: Al-Markaz Dirasat al-Wahidah al-'Arabiyah.

Al-Kattani, A. a.-H.K. 1982. Fabras al-Fahäris wa al-Itsbat. t.k.t.: Dar al-Gharb al-Islami.

Al-Muhtasib, A. M. 1997. Visi dan Paradigma Tafsir al-Qur'an. Bangil: Al-Izzah.

Al-Qasimi, M. J. 1978. Maḥāsin al-Ta'wül. Beirut: Dar al-Fikri al-Arabi.

. 2004. Qawäidu Tahdìs min Funūni 'Ulūm al-Hadis. Beirut: Mu'assasah alRisalah.

-. t.t.t. Dalä'il Al-Tauhìd. Kairo: Mathba'ah al-Madaniy.

Arabi, I. t.t.t.. Futubat al-Makkizyyah. Beirut: Dar al-Shadr.

Baqi, M. F. 2001. Mu"jam Mufahras li Alfäz al-Qur"ān al-Karim : Bi Hashiyah al-Mushaf alSyarifah. Kairo: Dar al-Hadis.

Commins, D. D. 2002. Guiding Mankind to Act on the Basic of Telegraphic Message. England: Oxford University Press.

Hadiwijono, H. 1989. Agama Hindu dan Budha. Jakarta: PT BPK Gunung Mulia.

Hamka. 1985. Tafsir Al-Az̧ har. Jakarta: Pustaka Panji Mas.

Hansen, U. S. 2008. Ikhtisar Ajaran Buddha. Yogyakarta: Insight.

Iqbal, M. 2002. Rekonstruksi Pemikiran Agama dalam. Yogyakarta: Lazuardi.

JR, A. H. 1997. Ilmu Agama. Jakarta: PT BPK Gunung Mulia.

Katsir, A. F. 2008. Kisah Para Nabi. Jakarta: Pustaka Azzam.

Manzur, A. I. (t.t.t.). Lisān al-Arab. Beirut: Dar Shadir.

Mughniyyah, M. J. 1993. Nubuwwah: Antara Doktrin dan Akal. Jakarta: Pustaka Hidayah.

Muthahhari, M. 1991. Falsafah Kenabian. Jakarta: Pustaka Hidayah.

Okawa, R. 2004. Hakikat Ajaran Buddha. Yogyakarta: Saujana Jogjakarta.

Saragi, J. J. 2000. Buddhisme sebagai Jalan Kehidupan. In Buddhisme: Pengarubnya dalam Abad Modern. Yogyakarta: Kanisius.

Shihab, M. Q. 2002. Tafsir l-Misbah, Pesan, Kesan, dan Keserasian Al-Qur'an. Jakarta: Lentera Hati.

Tim Penyusun Kamus Pusat Pembinaan dan Pengembangan. 1994. Kamus Besar Bahasa Indonesia. Jakarta: Balai Pustaka.

Zainuddin. 1992. Ilmu Taubid Lengkap. jakarta : Rhineka Cipta. 